Original Article

\title{
Repairability analysis of the energy gas turbine rotor blade second stage shroud by high-temperature brazing
}

\author{
Piotr Klimczuk \\ General Electric Company; piotr.klimczuk@ge.com
}

Received: 01.10.2020; Accepted: 12.03.2021

\begin{abstract}
The article considers the repair of the energy gas turbine rotor blade second stage shroud. The paper presents an analysis of the possibility of the repair consisting of the replacement of both labyrinth and honeycomb seals by the high-temperature brazing process. All the steps of the repair process were discussed and the results of microscopic metallographic evaluation using a light microscope and a scanning electron microscope were presented. SEM BSE microstructure and elements distribution of the joints has been presented. Several advantages related to the use of this technology were indicated.
\end{abstract}

Keywords: gas turbine; high-temperature brazing; honeycomb seal; labyrinth seal

\section{Introduction}

Energy gas turbines powered with natural gas are a reliable and efficient technology for generating electricity that is increasingly used [1]. Modern energy gas turbines are highly efficient devices developed on the basis of aircraft engines and can achieve electrical efficiency of $60 \%$ in an open system, and in a combined gas-steam system, even above 63\% [2]. Such a high electrical efficiency of a gas turbine can be achieved as a result of the development of modern design solutions and the use of heat-resistant materials, mainly based on nickel or cobalt. The elements of the hot part of the turbines operate in extremely difficult conditions: they can heat up to $550 \div 1100{ }^{\circ} \mathrm{C}$, are subjected to variable mechanical loads and are exposed to an aggressive gaseous environment [3]. Materials used for turbine parts should be heat-resistant, creepresistant (including thermal fatigue resistance). However, the extreme operating conditions make components made of advanced nickel and cobalt alloys degrade and require replacement or repair. The degradation of the components of the hot turbine is caused by several mechanisms, among which the main ones can be distinguished [4]:

- high temperature corrosion caused by chemical reactions between the component and certain contaminants such as salts, mineral acids or reactive gases;

- erosion, caused by hard particles hitting the flow surface;

- damage caused by fragments of wear-and-tear components of the turbine or accumulated deposits tearing off the components of the combustion chamber;

- creep caused by high levels of stress and temperature which also cause microstructural changes in turbine materials;

- thermo-mechanical fatigue, which is the cause of cracking caused by cyclic changes in thermal stresses over time, due to rotation, vibration or thermal cycles.

Power gas turbines are designed in such a way that components operating in demanding conditions can be replaced or repaired at strictly defined intervals. Repairs used in hot sections of gas turbines include, first of all, the reconstruction of the shape and surface of worn parts, the rebuilding of protective coatings and the repair of cracks [5]. One of the components that undergo periodic repair is the second stage rotor blade shroud (Fig. 1). The blade shroud in the gas turbine are positioned annularly around the entire circumference between the rotor blades and the turbine shell (Fig. 2). The purpose of the blade shroud is to provide a seal between the top of the blade and the surface of the casing. The aerodynamic leak between the blade and the casing may lead to a loss of power and a decrease in the efficiency of the turbine [6,7].

Depending on the degree of the turbine blade and the type of its shroud, different types of seals are used. One of the types of sealing used in both aircraft engines and gas turbines is a combination of a labyrinth seal and a honeycomb seal [9] (Fig. 3). 


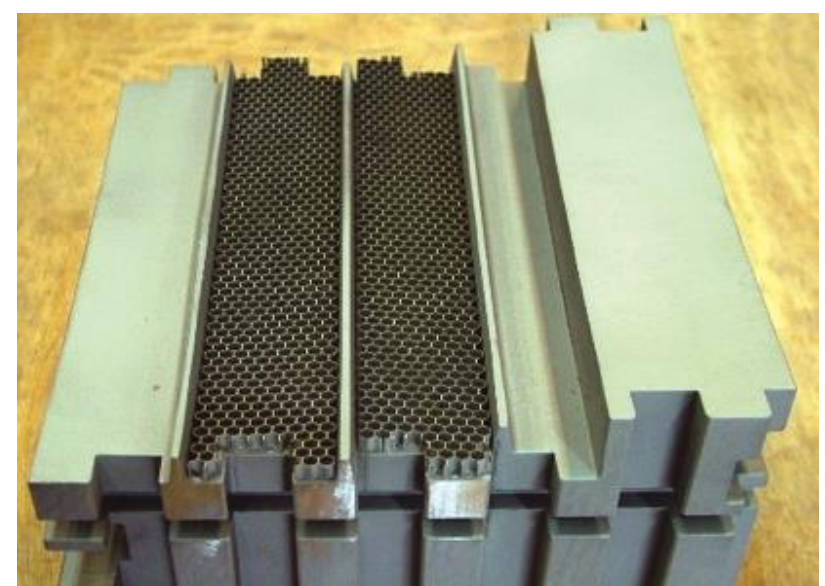

Fig. 1. Gas turbine second stage rotor blade shroud MS6001

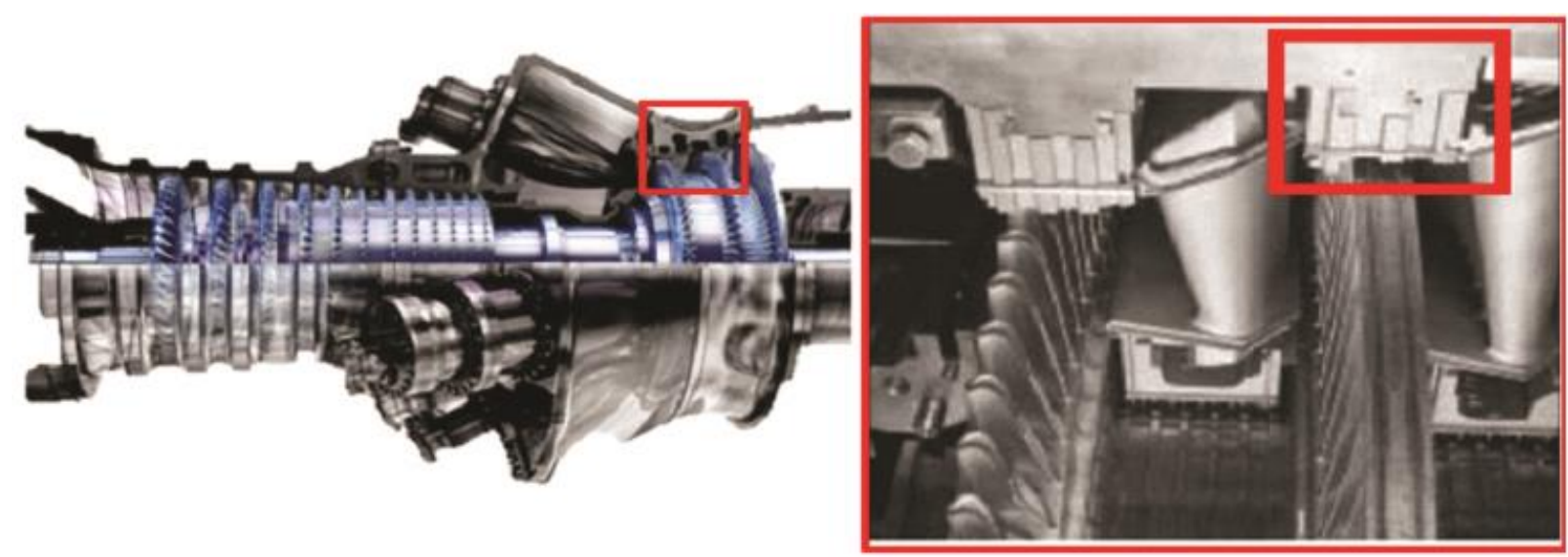

Fig. 2. Second stage rotor blade shroud location in a gas turbine [8]
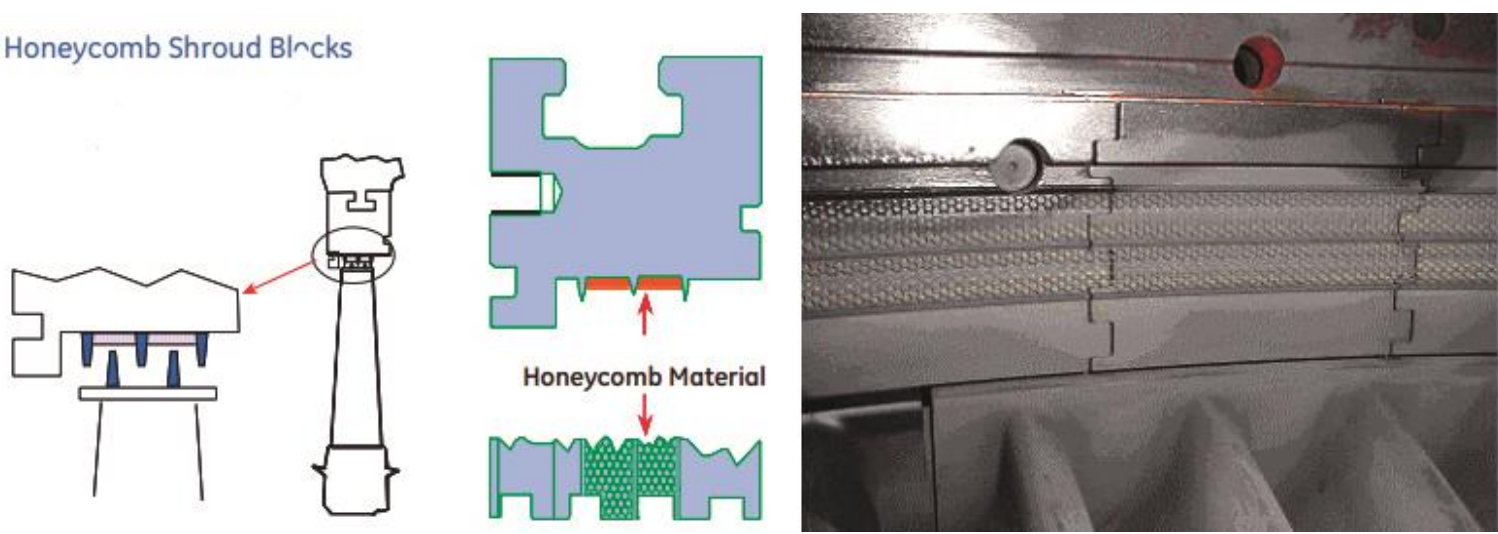

Fig. 3. Diagram of a labyrinth seal in combination with a honeycomb seal at the junction of the second stage of the rotor blade and its shroud [12]

The higher pressure ratio and the economical use of the cooling air require a low ground clearance, with the risk of contact and abrasion of the sealing surfaces. The use of a honeycomb seal in combination with a labyrinth seal allows for minimal leakage, tolerating to some extent abrasion [10]. The advantage of honeycomb seals over other solutions is also that the individual honeycomb cells act as low-pressure gascompressing elements. The gas seal phenomenon is that the gases flowing through the honeycomb seal are inhibited by the capillary walls, reflect off them and create additional resistance to the flowing air. As a result, the phenomenon of dynamic gas sealing of the engine is observed [11]. During operation of the turbine, the sealing surfaces are exposed to a number of factors causing wear. One of them is hightemperature corrosion caused by the action of a stream of hot, pressurized exhaust gases. As a consequence, the thickness of the sealing surfaces is reduced, and the labyrinth seals are cracked as a result of thermo-mechanical fatigue. In extreme cases, we can also deal with friction of the sealing surfaces. Repairing the rotor's blade shroud requires not only replacing the honeycomb seal, but also rebuilding the edge of the labyrinth seal. One of the methods used to rebuild the shape of a labyrinth seal is manual TIG 
welding. This method is time-consuming and may generate imperfections due to reduced weldability of the degraded material and thinned edges of the seal. In this study, an analysis of the repair possibilities consisting in the replacement of honeycomb and labyrinth seals using the brazing process was carried out.

\section{Materials and research methodology Materials used for blade shrouds}

Turbine rotor blade shrouds are made of heat-resistant and creep-resistant steels or nickel or cobaltbased superalloys. The second stage turbine blade shroud, which is the subject of the research, is an element made of AISI 310 austenitic steel with the chemical composition given in Table I. It is a high-alloy stainless steel for high temperature operation [13].

Table I. Chemical composition of AISI 310 steel [ASTM A240/A240M]

\begin{tabular}{ccccccccc}
\hline $\begin{array}{c}\text { Material } \\
\text { (wt.\%) }\end{array}$ & Fe & Ni & Cr & Mn & Si & C & S & P \\
\hline SS310 & rest & $19 \div 22$ & $24 \div 26$ & 2 & 1.5 & 0.25 & 0.03 & 0.045 \\
\hline
\end{tabular}

\section{Materials used for honeycomb seals}

Honeycomb seals (Fig. 4) used in the rotor's casings of the blades are usually made of nickel alloys with the trade name Hastelloy X or Haynes 214, characterized by high resistance to oxidation and maintaining strength properties at temperatures up to $1200{ }^{\circ} \mathrm{C}$ [14]. The chemical composition of these alloys is given in Table II.

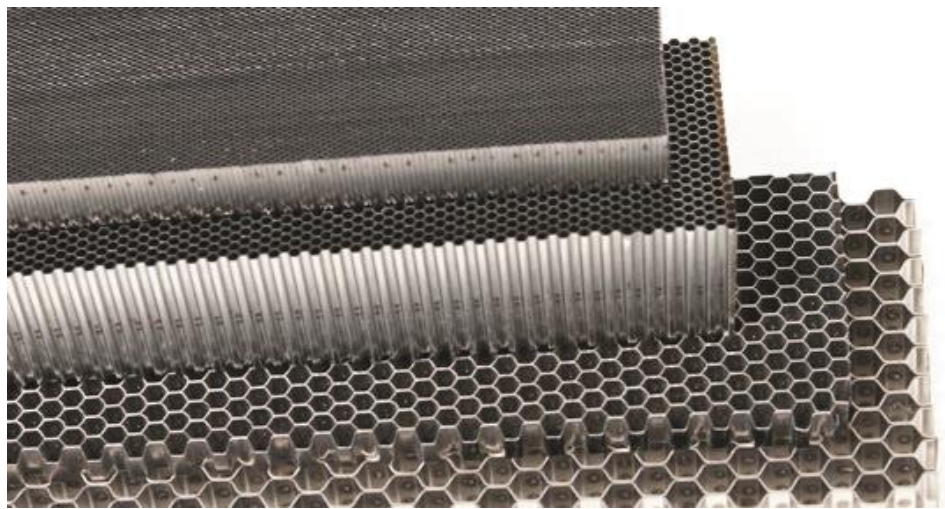

Fig. 4. The examples of honey-comb seals [www.indyhoneycomb.com/engine-seal-honeycomb]

Table II. Chemical composition of Hastelloy-X and Haynes 214 [www.haynesintl.com]

\begin{tabular}{ccccccccccccccc}
\hline $\begin{array}{c}\text { Material } \\
\text { (wt.\%) }\end{array}$ & $\mathbf{N i}$ & $\mathbf{C r}$ & $\mathbf{F e}$ & $\mathbf{M o}$ & $\mathbf{C o}$ & $\mathbf{W}$ & $\mathbf{C}$ & $\mathbf{M n}$ & $\mathbf{S i}$ & $\mathbf{B}$ & $\mathbf{N b}$ & $\mathbf{A l}$ & $\mathbf{T i}$ \\
\hline Hastelloy-X & rest & 22 & 18 & 9 & 1.5 & 0.6 & 0.1 & $1 \mathrm{max}$ & $1 \mathrm{max}$ & $\begin{array}{c}0.008 \\
\max \end{array}$ & $\begin{array}{c}0.5 \\
\max \end{array}$ & $\begin{array}{c}0.5 \\
\max \end{array}$ & $\begin{array}{c}0.15 \\
\max \end{array}$ \\
\hline $\begin{array}{c}\text { Material } \\
\text { (wt.\%) }\end{array}$ & $\mathbf{N i}$ & $\mathbf{C r}$ & $\mathbf{A l}$ & $\mathbf{F e}$ & $\mathbf{C o}$ & $\mathbf{M n}$ & $\mathbf{M o}$ & $\mathbf{T i}$ & $\mathbf{W}$ & $\mathbf{N b}$ & $\mathbf{S i}$ & $\mathbf{Z r}$ & $\mathbf{C}$ \\
\hline Haynes-214 & rest & 16 & 4.5 & 3 & 2 max & $\begin{array}{c}0.5 \\
\max \end{array}$ & $\begin{array}{c}0.5 \\
\max \end{array}$ & $\begin{array}{c}0.5 \\
\max \end{array}$ & $\begin{array}{c}0.5 \\
\max \end{array}$ & $\begin{array}{c}\text { max } \\
\text { max }\end{array}$ & $\begin{array}{c}\text { max } \\
\text { max }\end{array}$ \\
\hline
\end{tabular}

\section{Brazing materials used for brazing}

Materials used for brazing honeycomb seals are usually nickel-based materials with the addition of boron or boron and/or silicon as an element that lowers the melting point. In this study, AWS BNi-2 (AMS 4777) braze was used. The chemical composition is given in Table III.

Table III. Chemical composition of brazing consumable AWS BNi-2/AMS 4777 [11]

\begin{tabular}{ccccccc}
\hline AWS\&AMS classification & \multicolumn{7}{c}{ Content of elements (wt.\%) } \\
& Cr & Fe & Si & C & B & Ni \\
\hline AWS BNi-2/AMS 4777 & 7.0 & 3.0 & 4.5 & 0.06 & 3.2 & rest \\
\hline
\end{tabular}




\section{Characterization of the microstructure}

The test specimens were collected by the EDM method with the use of a wire erosion machine. After their mounting, the metallographic specimens for the tests were ground on $\mathrm{SiC}$ abrasive papers with gradation from $\# 400$ to $\# 1200$ and polished with a diamond suspension with a grain size of $3 \mu \mathrm{m}$. Observations of the microstructure of the samples were made in the non-etched state and after etching with Kalling's reagent in a metallographic microscope and a scanning electron microscope equipped with a microanalysis accessory (EDS Energy Dispersive Spectroscopy). The metallographic tests were carried out based on the internal specifications of the company.

\section{Results of the research}

\section{Replacement of the honeycomb seals}

Due to the necessity of replacement, worn seals are removed using a milling or grinding process. After removing the used seals, the obtained surface is not devoid of the remnants of the previous brazed joint (Fig. 5), hence the first step in developing the repair process was to analyze the effect of the remnants of the removed brazed joint. For this purpose, a study of the microstructure and chemical composition in the micro-areas was carried out, chemical elements included in the braze residue were identified and the thickness of the oxide layer present in the braze joint residue was determined. The results of the analysis are presented in Figures 5 $\div 9$. The layer of silicon oxides reaches a depth of $0.08 \mathrm{~mm}$ (Fig. 9). On the basis of the obtained test results, it was recommended to completely remove the remaining braze to the surface of the base material due to the risk of the influence of oxides on the wettability during braze repair.

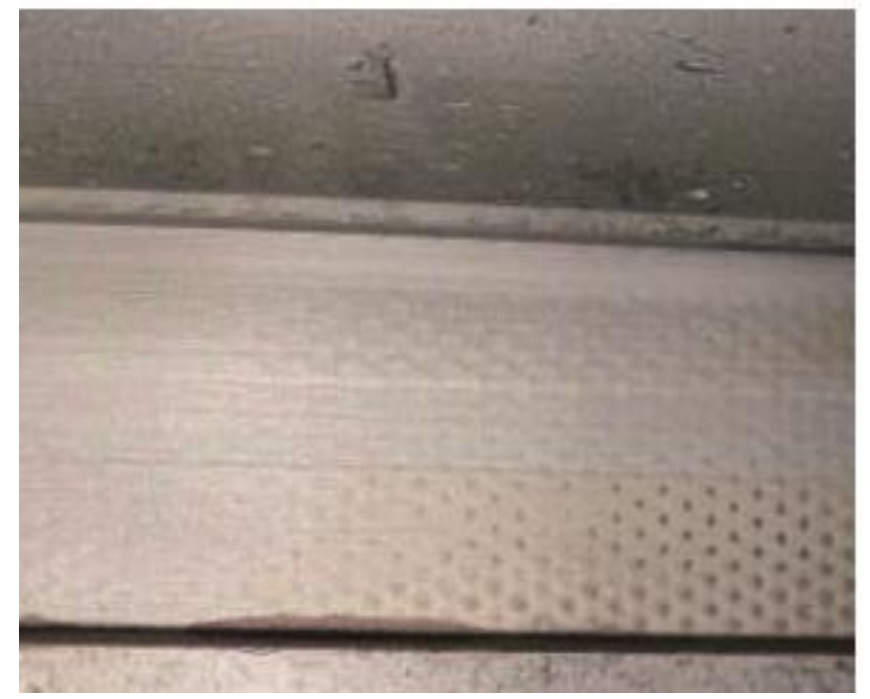

Fig. 5. Residual of a brazed joint after removing the honeycomb seal

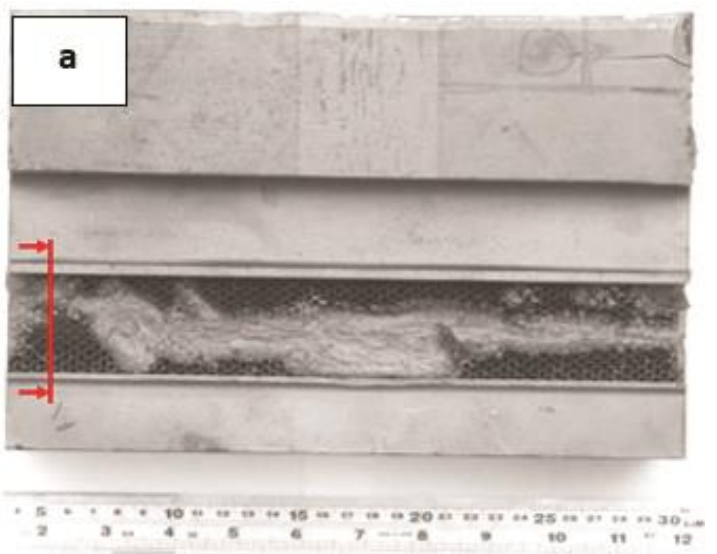

(a)

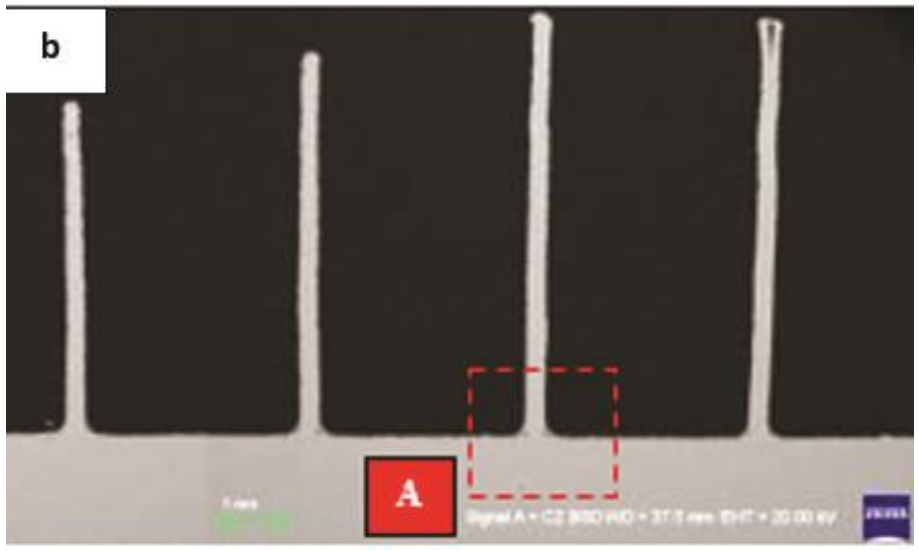

(b)

Fig. 6. a) Location of the sample cut for testing: b) location of the honeycomb seal wall joint with the substrate further analyzed 


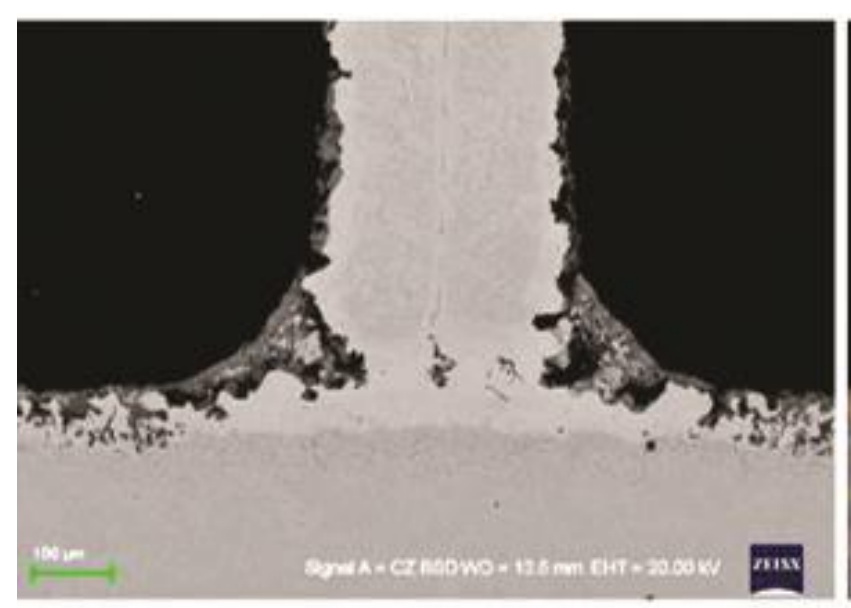

(a)

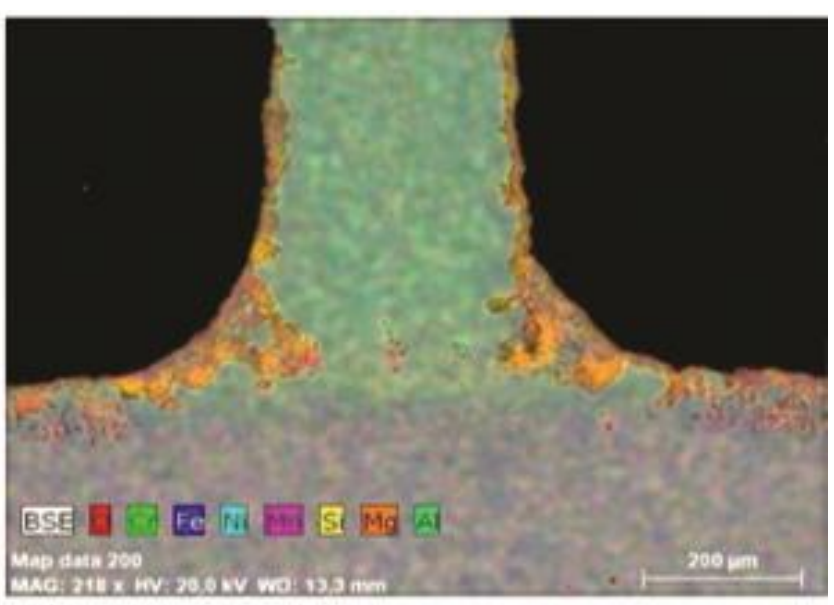

(b)

Fig. 7. SEM (BSE) image of a brazed joint: a) distribution of elements on the cross-section of a braze joint; $b$ ) between the honeycomb seal and the surface of the shroud
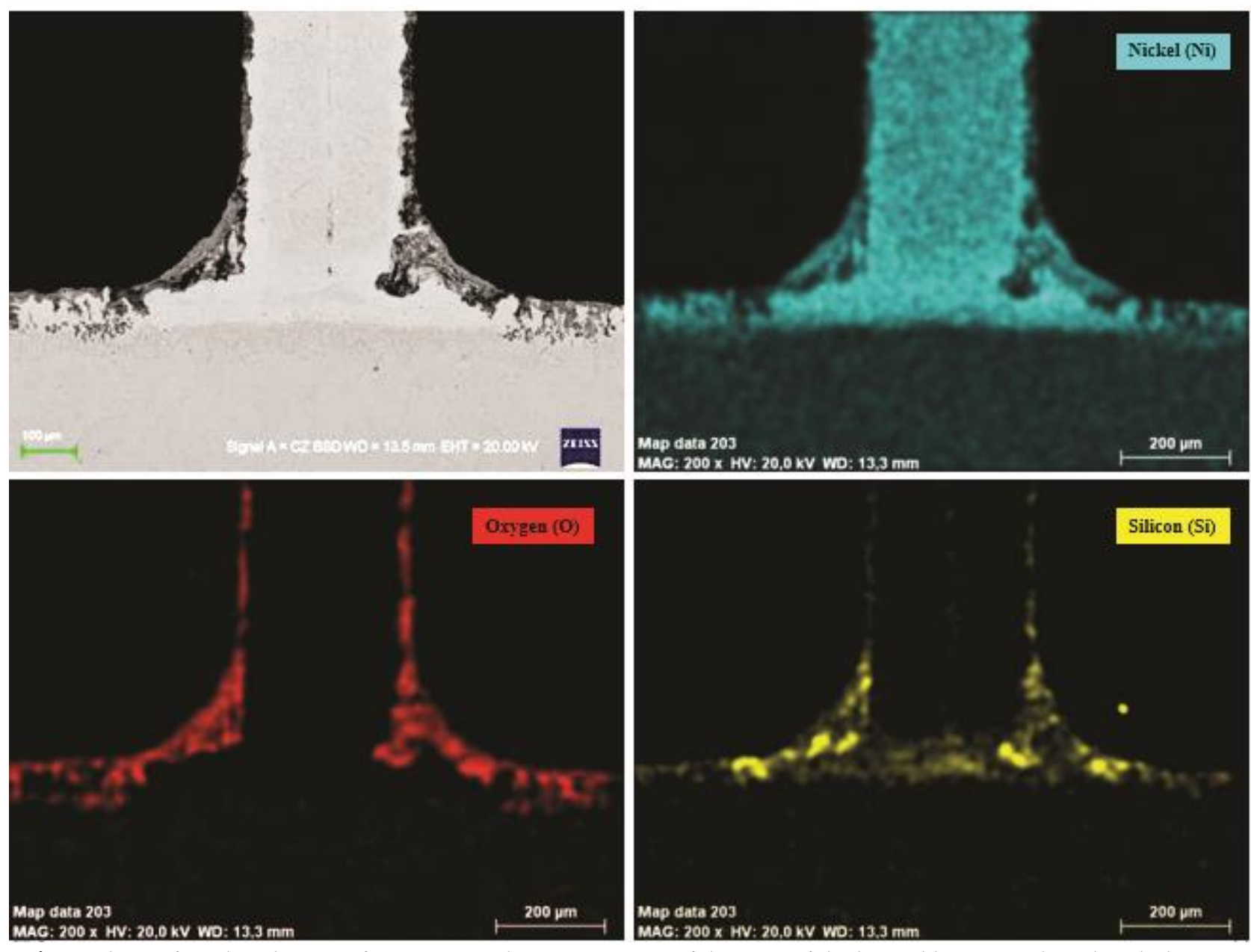

Fig. 8. The surface distribution of $\mathrm{O}, \mathrm{Si}$, $\mathrm{Ni}$ on the cross-section of the joint of the brazed honeycomb seal with the surface of the shroud

\section{Replacement of the labyrinth seals of the blade shroud}

Depending on the operating conditions of the gas turbine and, consequently, the size of the damage to the parts, the repair of the blade shroud may be limited only to replacing the honeycomb seals and restoring the material properties of the parts by carrying out appropriate heat treatment. An example of a segment of the rotor's blade shroud after operation in a turbine is shown in Figure 10a. It happens, however, that the teeth of the labyrinth seal also require rebuilding of the edges or complete rebuilding of their surface as a result of wear, in particular as a result of high-temperature oxidation or friction. The most common method of repairing such wear is manual welding using the TIG process, but due to the large degradation of the base 


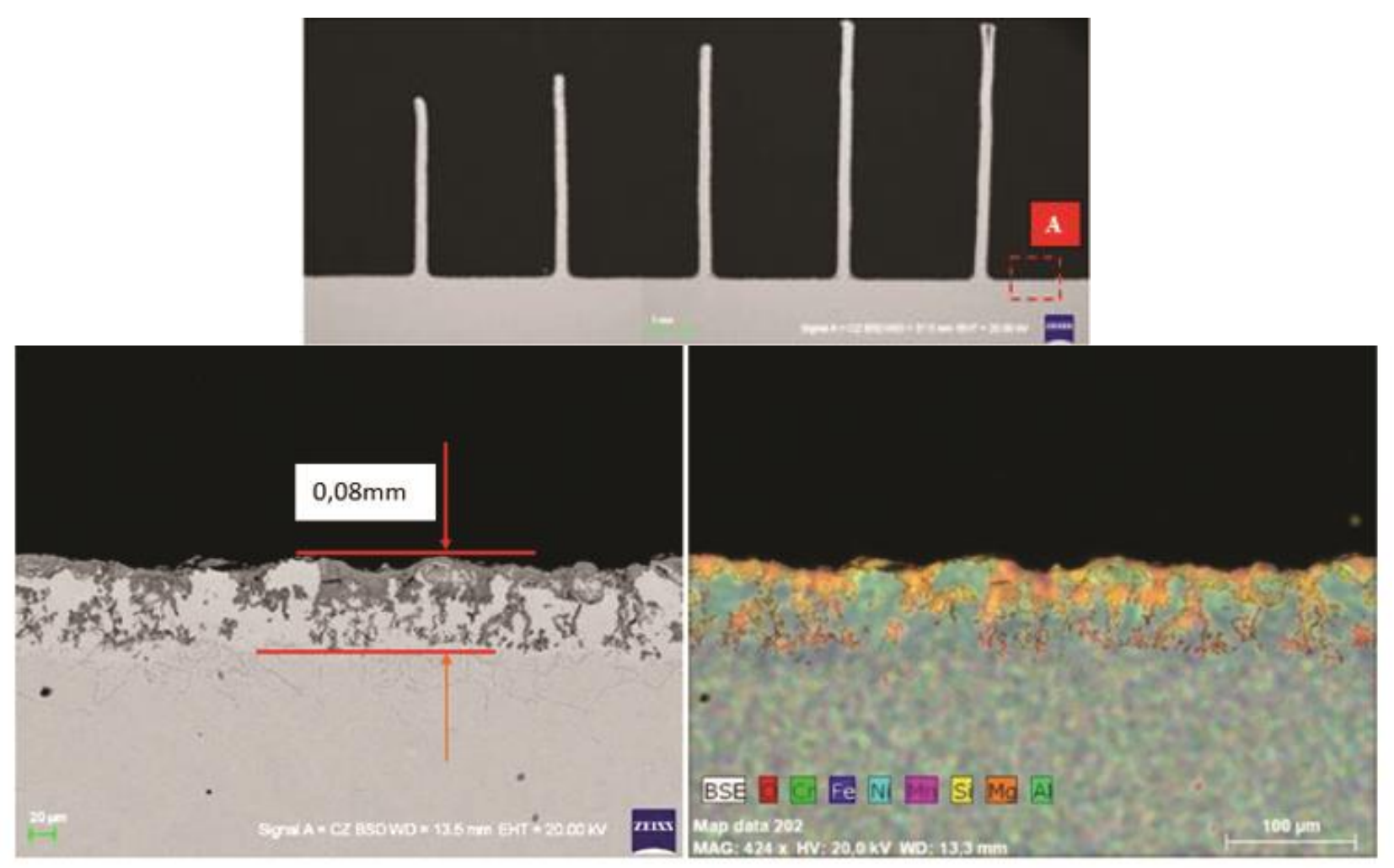

Fig. 9. a) SEM BSE image of the braze joint; b) distribution of chemical elements

material and the rapid overheating of the thin edge of the labyrinth seal, this process is characterized by a large number of defects, mainly in the form of cracks, and thus, requires repair of welds. As an alternative to the time-consuming welding process, it was proposed to use the technology of replacing the teeth of the labyrinth seal using the high-temperature brazing process and the use of a single brazing cycle, during which both the labyrinth and honeycomb seals are joined to the surface of the rotor's blade shroud. The next steps of this repair technology are shown in figures $10 \mathrm{~b} \div 12$. During the process of removing the old honeycomb seal, grooves are prepared on the same CNC machine, which are milled in the place of damaged teeth of the labyrinth seal. In this place, new teeth are installed, previously made of the same material as the blade's casing, or of a material with better properties, mainly better resistance to hightemperature corrosion. The next step is to install honeycomb seals which are previously impregnated with brazing tape and then pre-fix them prior to the brazing process using a resistance welding process. At the connection of the teeth of the labyrinth seal with the surface of the blade shroud, a brazing paste of the same composition as the tape used in the honeycomb seal is additionally applied, and the entire area around the elements to be joined is masked with stop-off paste, which prevents braze from flowing into undesirable places.

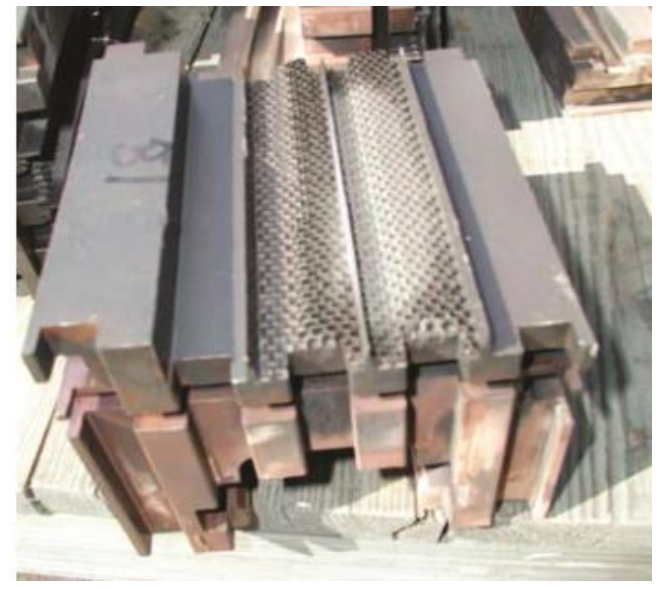

(a)

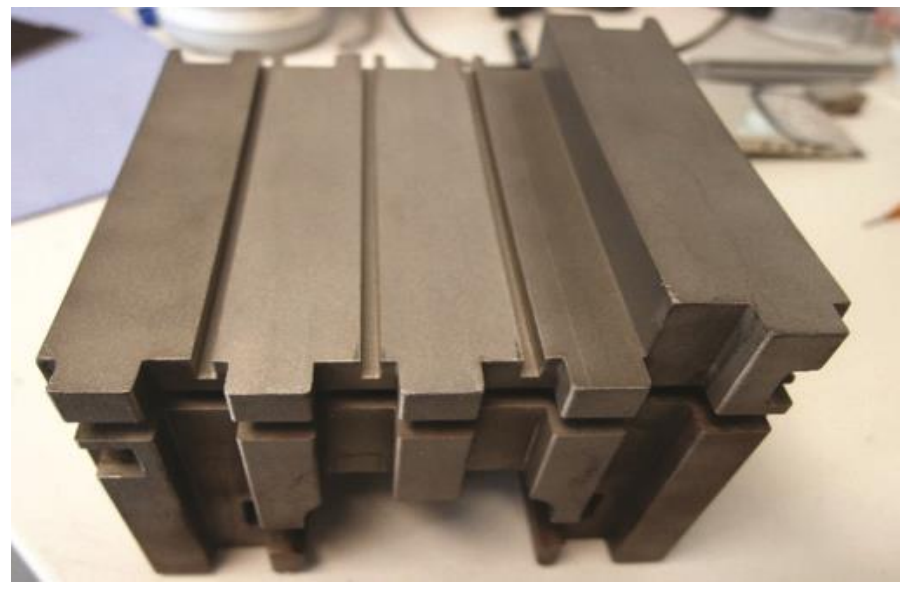

(b)

Fig. 10. Second stage turbine rotor blade shroud segment: a) after operation [10]; b) after preparing the surface for brazing labyrinth and honeycomb seals 


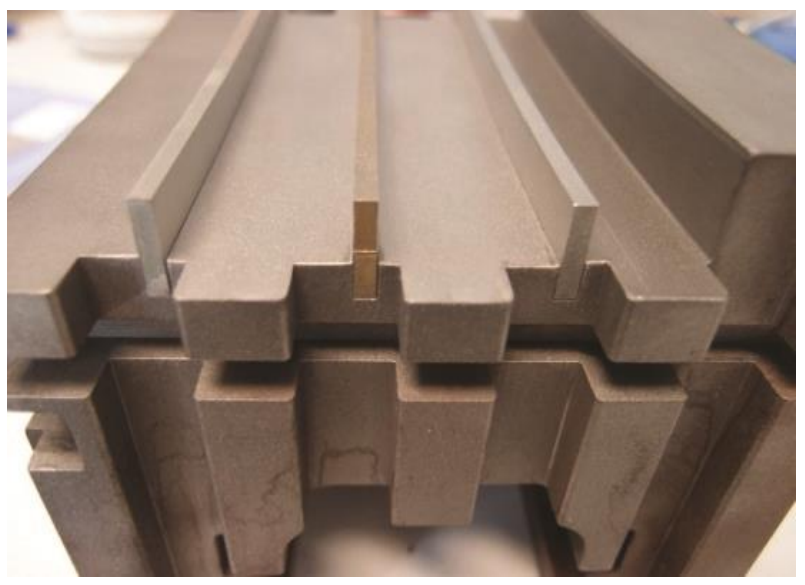

(a)

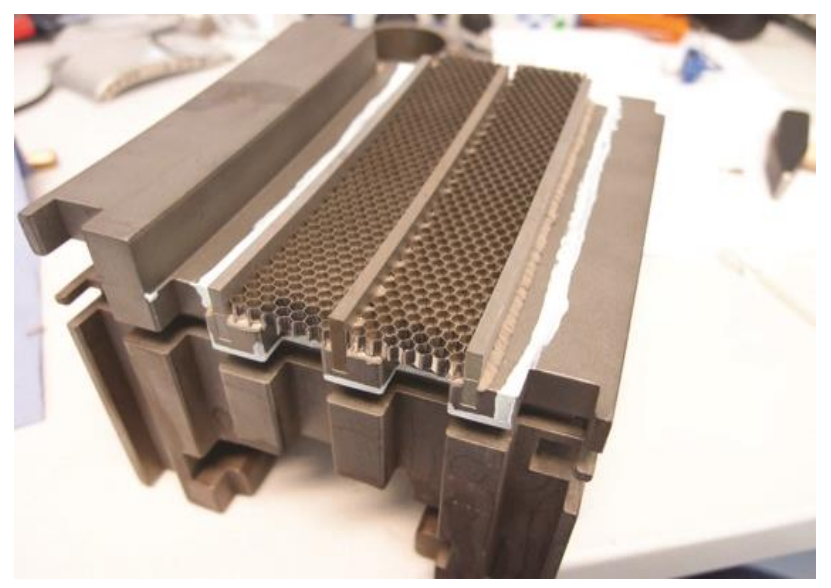

(b)

Fig. 11. a) Assembly of the labyrinth seal teeth in the blade shroud; b) blade shroud with honeycomb seals fitted and brazing paste and stop-off paste applied

The parts are then subjected to a high-temperature brazing process in a vacuum furnace. Photos of the parts after brazing are shown in figure 12. In the next step, all the braze joints are visually inspected, while braze joints of honeycomb seals are additionally visually inspected using a borescope to assess continuity. Visual and borescope examinations are performed based on the company's internal specifications. The visual inspection of the braze joints did not reveal any braze incompatibilities and ended with a positive result. As part of the qualification of the first piece of the new repair process, one of the segments was subjected to destructive testing to assess the quality of the brazed joint of the seal and the surface of the blade shroud.

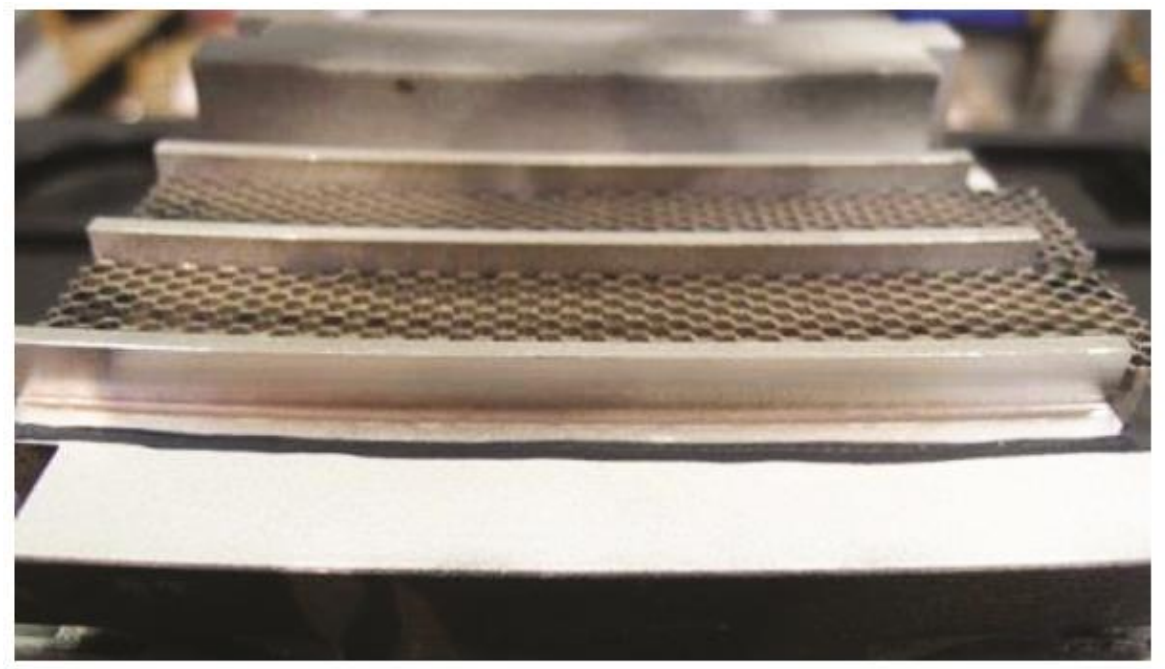

Fig. 12. Blade shroud after the high temperature brazing

Figure 13 shows the cross-sections of the brazed elements made using a light microscope. Both the braze joint between labyrinth seals and honeycomb seals and the surface of the blade shroud complies with the quality requirements, free from any defects in the form of voids, cracks, porosity or linear eutectics that could weaken the strength of such a joint. We can observe the correctly selected width of the brazing gap for the teeth of the labyrinth seal (A-C), which allowed for an appropriate capillary action allowing the gap to be completely filled with braze. The amount of brazing paste used was sufficient for both seals, which is important especially in the case of honeycomb seals, in which the total filling of the cell with braze cannot exceed $25 \%$ of the seal's height (D-G). 

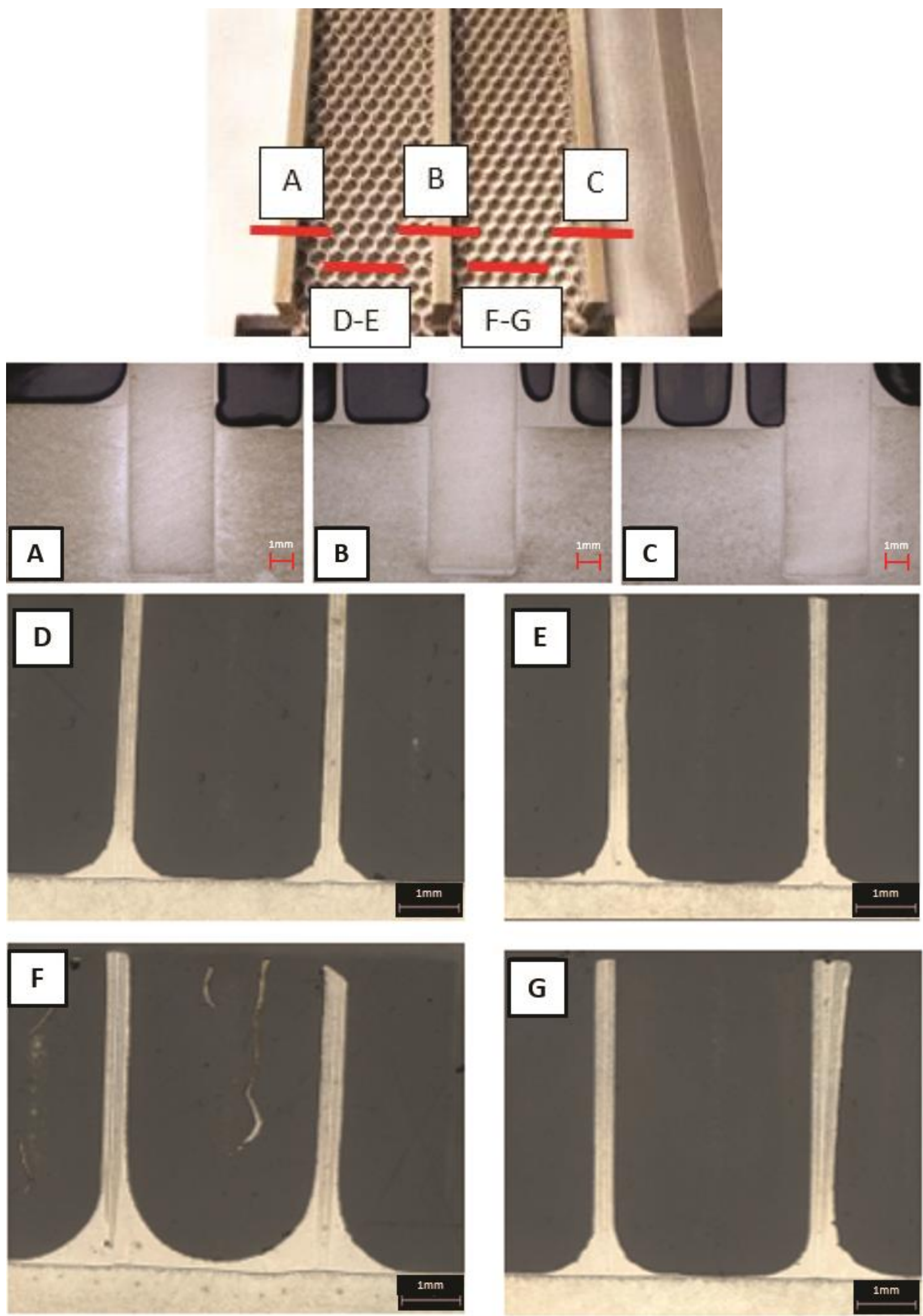

Fig. 13. Microstructure of brazed joints between the blade shroud and honeycomb and labyrinth seals 


\section{Conclusions}

High-temperature brazing in a vacuum furnace is one of the most promising processes for replacing honeycomb and labyrinth seals in gas turbine components during repairs. The development of repair technologies using the high-temperature brazing process requires controlling many factors that may affect the quality of the finished product, i.e. cleanliness of the surface before brazing, the appropriate size of the brazing gap and the amount of brazing material used. Using the same process and brazing cycle to replace honeycomb seals and the teeth of labyrinth seals in the same repaired component brings a number of benefits, such as:

- savings resulting from the reduction of time and number of performed operations compared to traditional manual welding;

- the possibility of repairing components in batches of a dozen or even several dozen in one furnace process, depending on the size of the furnace;

- eliminating the need to apply corrections in the manual welding process;

- the possibility of using better materials for the teeth of the labyrinth seal, allowing for longer operation at higher temperatures and a very high quality of the repair.

Thanks to comprehensive repair, it is possible not only to restore the functionality of the part before its next cycle of operation in the turbine, but also to extend its life and increase its operating parameters thanks to the use of materials with better properties.

Funding: This research received no external funding

Acknowledgments: The author would like to thank his $\mathrm{PhD}$ supervisors, professor Jarosław Mizera and dr. hab. eng. Ryszard Sitek, for their contribution, proficient comments and support during the creation of the article.

Conflicts of Interest: The author declares no conflict of interest

\section{References}

[1] Wright I.G., Gibbons T.B., Recent developments in gas turbine materials and technology and their implications for syngas firing. International Journal of Hydrogen Energy, 2007, Vol. 32(16), 3610-3621.

https://doi.org/10.1016/j.ijhydene.2006.08.049

[2] https://www.powermag.com/ge-unveils-new-h-class-gas-turbine-and-already-has-a-first-order/

[3] Sims C.T., Stoloff N.S., Hagel W.C.: Superalloys II, Wiley\&Sons, New York, 1987.

[4] Kurz R, Brun K., Degradation in Gas Turbine Systems. Journal of Engineering for Gas Turbines and Power, 2000, Vol. 123(1). https://doi.org/10.1115/2000-GT-0345

[5] Pallos K. J., Gas Turbine Repair Technology [GER-3957B online], GE Power Systems, Atlanta, 2004

[6] Rolls-Royc plc, The Jet Engine, The Technical Publications Department Rolls-Royce plc, Derby, 1986

[7] Ginter T., Bouvay T., Uprate Options for the MS7001 Heavy Duty Gas Turbine [GER-3808C online], GE Energy, Atlanta, 2012

[8] https://www.ge.com/content/dam/gepower-pgdp/global/en_US/documents/service/2018-ps-catalog.pdf

[9] Sporer D., Fortuna D., Selecting Materials for Brazing a Honeycomb in Turbine Engines. Welding Journal, 2014, Vol. 93(2), 44-48.

[10] Munz O., Pychynski T., Schwitzke C., Bauer H.-J, Continued Experimental Study on the Friction Contact between a Labyrinth Seal Fin and a Honeycomb Stator: Slanted Position, Aerospace, 2018, Vol. 5(3), 82. https://doi.org/10.3390/aerospace5030082

[11] Babul T., Kowalski S., Jakubowski J., Senkara J., Kopeć J., Turowska L., Lutowanie próżniowe uszczelnień ulowych w aparatach kierujących wykonanych ze stopów Hastelloy i Inconel z zastosowaniem lutu NiCrSiB, Przegląd Spawalnictwa, 2007, Vol. 79(9), 124-129.

[12] https://www.ge.com/content/dam/gepower-gdp/global/en_US/documents/technical/ger/ger-4217b-uprateoptions-ms6001-heavy-duty-gas-turbine.pdf

[13] Chandler H., Heat Treater's Guide: Practices and Procedures for Irons and Steels, ASM International, USA, 1995. Przybyła B., Zapałowicz Z., Review of methods for sealing aviation turbine rotors. Publishing Hous of Rzeszów Univeristy of Technology, Vol. 291, Mechanika 87, 235-243, 2015.

(C) 2021 by the authors. Submitted for possible open access publication under the terms and conditions of the Creative Commons Attribution (CC BY) license (http://creativecommons.org/licenses/by/4.0/). 